\title{
Dynamic and growth of the forests of the Isla del Coco National Park, Costa Rica
}

\section{Rafael Bonilla-Mata ${ }^{1 *} \&$ Luis Guillermo Acosta-Vargas ${ }^{1,2}$}

1. Instituto Tecnológico de Costa Rica, Escuela de Ingeniería Forestal, Cartago, Costa Rica; rbonillam24@gmail.com; lacosta@itcr.ac.cr, acosta.luisguillermo@gmail.com

2. Doctorado en Ciencias Naturales para el Desarrollo (DOCINADE), Instituto Tecnológico de Costa Rica, Universidad Nacional, Universidad Estatal a Distancia, Costa Rica.

* Correspondence

Received 05-II-2019. Corrected 12-VI-2019. Accepted 18-IX-2019.

\begin{abstract}
Introduction: Islands are essential for world biodiversity. Isla del Coco National Park is an oceanic island in which a tropical rain forest grows; however, its ecology and the effect of introduced species are poorly understood. Objective: To evaluate the mortality, recruitment, regeneration, and growth of forest canopy species. Methods: We measured 15 permanent sampling plots (PSP), nine in the Premontane Pluvial Rainforest (PPR), and six in the Cloud Forest (CF); trees with $\mathrm{DBH}>5 \mathrm{~cm}$ (diameter at breast height) were measured. The sampling regeneration was done within every PSP, along two transects of 1 X $50 \mathrm{~m}$. Data analyses were performed using data obtained in 2006 and 2012 as baseline. Results: In the period 2012-2017, the annual mortality rate in the PPR was $5.75 \%$ and for CF $6.31 \%$. The yearly recruitment rate in the PPR was $5.38 \%$, and $5.90 \%$ for CF. For the PPR the total registered regeneration was 5656 individuals and 8700 for the CF. Sacoglottis holdridgei reported the highest mortality and the lowest values of recruitment and regeneration. Forest structure fits the inverted J model for most of the tropical forests. Sacoglottis holdridgei define the forest population structure above DBH $>20 \mathrm{~cm}$. But, diameters under $20 \mathrm{~cm}$ are strongly influenced by $H$. succosa, because it reported the highest abundance of regeneration and recruitment. The annual average increase in diameter between forest was statically different ( $\mathrm{p}=0.0414 ; \mathrm{N}=15), 0.36 \mathrm{~cm} /$ year in the PPR, and $0.33 \mathrm{~cm} /$ year the in CF. Conclusions: The PPR and CF differ in the patterns of mortality, recruitment, and regeneration, confirming the uniqueness of these ecosystems. More successful regeneration of H. succosa will lead to changes in structure and composition of forests, mainly PPR. The changes in forest structure will have a strong impact on epiphytic flora, microclimate conditions, and bird nesting such as Gygis alba (White Tern) due to the loss of mature trees of Sacoglottis. The low regeneration of $S$. holdridgei is associated with the presence of introduced herbivores, their management is needed for restoring the forest.
\end{abstract}

Key words: Forest structure; mortality; recruitment; regeneration; growth; basal area.

Bonilla-Mata, R., \& Acosta-Vargas, L. G. (2020). Dynamic and growth of the forests of the Isla del Coco National Park, Costa Rica. Revista de Biología Tropical, 68(Suppl. 1), S89-S102.

Isla del Coco National Park (ICNP) is an oceanic island located in the Eastern Pacific and has belonged to Costa Rica since 1869. It was declared a National Park in 1978 (Bolívar, Rovinsky, \& Ching, 2000), and is considered a natural laboratory for the study of biodiversity (Madriz, 2009).
The Isla del Coco's forests are evergreen, thanks to the high humidity. They are dominated by the endemic tree Sacoglottis holdridgei (Cuatec, 1964) (Humiriaceae); that reaches 25 meters in height and a meter in diameter. (Porras-Jiménez, 2012, Trusty, Kesler, \& Delgado, 2006). The crowns are the support 
for epiphytes and nesting for marine birds including the migratory species Gygis alba (White Tern). The understory is clear, mostly dominated by bushes and the grass Hypolytrum amplum (Poepp. \& Kunth in Kunth, Enum., 1837) (Cyperaceae, Trusty et al., 2006), and regeneration of canopy species are scarce (Acosta-Vargas, 2016). The forest has a low diversity compared with the Costa Rica continental forests. Plant diversity reached 296 species of vascular plants, and ferns are the most diverse group (Estrada-Chavarría, Sánchez-González, \& Rodríguez-González, 2020). Thirty-eight species are endemic, including the trees S. holdridgei and Cecropia pittieri (B.L. Rob. 1912) (Urticaceae), and the tree fern Cyathea alfonsiana (L. D. Gómez, 1971) (Cyatheaceae, Trusty et al., 2006, EstradaChavarría et al., 2020).

The study of the flora of the ICNP, began when the naturalist George W. Barclay, collected plant specimens in the year 1838 (Zamora, 2008). Recent studies of Porras-Jiménez (2012) started the documentation of tree mortality in the forest of Isla del Coco, leading to changes in the floristic composition and vegetation structure. This study aroused interest in additional research focused on population status and structural changes in the forests (AcostaVargas, 2016). In general, the investigation had been focused on flora descriptions (Rivera, 2006; Trusty et al., 2006; Zamora, 2008). Topics related to forest dynamics, forest structure, growth rates, and ecological processes are poorly known in Isla del Coco.

The forest's dynamics are linked to mortality and recruitment (Lewis et al., 2004). Finegan (1992) mentions that disturbance plays a significant role, since the death of individuals causes the formation of clearings, activating natural regeneration, and thus keeping the diversity and structure of the forest. Alterations in the natural regeneration process, conditions the permanence of the forest structure and plants' composition. Those effects are stronger in insular ecosystems, where some ecological processes are absent (Madriz, 2009). The problems of natural regeneration become bigger and more complex with the introduction of large herbivores onto the islands. Herbivores impact the development of the forest due to their branch grazing, changing growth patterns and altering the abundance and survival of plant regeneration (Dirzo, 2001). Herbivores can also affect the availability of tree seeds and their dispersion, which is a critical process for forest maintenance (Janzen, 1970). In addition, they can cause alterations to the soil of the forests via compaction (Sierra, 2001). The introduction of the feral pigs to ICNP was recorded (Sus scofra) in 1793, and whitetailed deer (Odocoileus virginianus) in 1935 (Montoya, 2016).

Forest growth is assessed by monitoring the size increase of trees over time and reported in terms of diameter, basal area, or volume increase (Louman, Quiros, \& Nilsson, 2001). Growth rate can be affected by factors such as site conditions (light, heat, humidity), soil (nutrients, $\mathrm{pH}$ ), competition between individuals, and the species performance (Castillo-Ugalde, 1991; Valerio, Esquivel, \& Salas, 1998; Gadow, Sanchez, \& Alvarez, 2007; Quesada-Monge, Castillo-Ugalde, Lobo-Segura, \& Barrantes, 2010; Bowman, Brienen, Gloor, Phillips, \& Prior, 2013). This investigation was carried out to describe the forest population status and its species, for determining threats and actions to restore and preserve the forests of Isla del Coco.

\section{MATERIAL AND METHODS}

Site: Isla del Coco National Park (ICNP) is in the Eastern Pacific in the coordinates $05^{\circ} 30^{\prime} 57^{\prime \prime} \mathrm{N} \& 87^{\circ} 05^{\prime} 40^{\prime}$ ' W; at an approximate distance of $500 \mathrm{~km}$ from Puntarenas, Costa Rica. It has a terrestrial area of $24 \mathrm{~km}^{2}$ and a marine protected area of $2011 \mathrm{~km}^{2}$ (SINAC, 2016). It is of volcanic origin, and the only emerging point of the Cocos Ridge (Castillo et al., 1988). Isla del Coco receives an annual rainfall from 5000 to $7000 \mathrm{~mm}$. The average annual temperature of $25.5{ }^{\circ} \mathrm{C}$, the minimum is of $23.1{ }^{\circ} \mathrm{C}$ and the maximum is of $27.6^{\circ} \mathrm{C}$ (Herrera, 1986; Gutiérrez-Fonseca, 
Ramirez, Umaña \& Springer, 2013; Fig. 1). There are two forest types are in Isla del Coco: the Premontane Pluvial Rainforest (PPR) located under 300 m.a.s.l (meters above sea level). with an area of $18.51 \mathrm{~km}^{2}$ and the Cloud Forest (CF) from 300 to 634 m.a.s.l. covering an area of $4.68 \mathrm{~km}^{2}$ (Porras-Jiménez, 2012).

Experimental design: The baseline for this study consists of data obtained from 15 Permanent Sampling Plots (PSP) of $50 \times 50 \mathrm{~m}$ ( $0.25 \mathrm{ha})$, subdivided into subplots of $10 \times 10$ $\mathrm{m}$ and established in the altitudinal gradient. The first nine PSP were placed in the PPR in 2006 (Rivera, 2006), and measured again in 2012 and 2017 giving six and eleven years of observation. The second group of six PSP were placed in the CF in 2012 (Porras-Jiménez, 2012), and measured again in 2017 giving five years of observation (Fig. 1). All individuals with a diameter at breast height $(\mathrm{DBH}) \geq 5 \mathrm{~cm}$ were measured in diameter and height.

Isla del Coco has a low tree diversity, and the forest structure depends on two species in both forests. Sacoglottis holdridgei, which is a dominant species accounting around $60 \%$ of the canopy trees, and the canopy codominant Ocotea insularis (Meisn. Mez, 1889) (Lauraceae). In the middle canopy in the PPR the most abundant species are Henriettea succosa (Aubl. DC. 1828 and Henriettella odorata Markgr. 1941), (Melastomataceae). In the CF, the middle canopy is dominated by the tree fern Cyathea alfonsiana (Cyatheaceae) that is accompanied by Miconia dodecandra Cogn. 1887 (Melastomataceae), Myrsine pellucidopunctata Oerst. 1862 (Primulaceae). The species cited before were included for their higher abundance and importance in the future of the forest structure.

Mortality: The annual mortality rate was obtained using the Nebel et al., (2001) model:

$$
\mathrm{Rm}=(\ln (\mathrm{No})-\ln (\mathrm{No}-\mathrm{Nm})) / \Delta \mathrm{t},
$$

Rm: Mortality rate, No: Number of individuals in the first measurement, Nm: Number of dead

\section{Permanent Sampling Plots (PSP) in Isla del Coco National Park, Costa Rica}

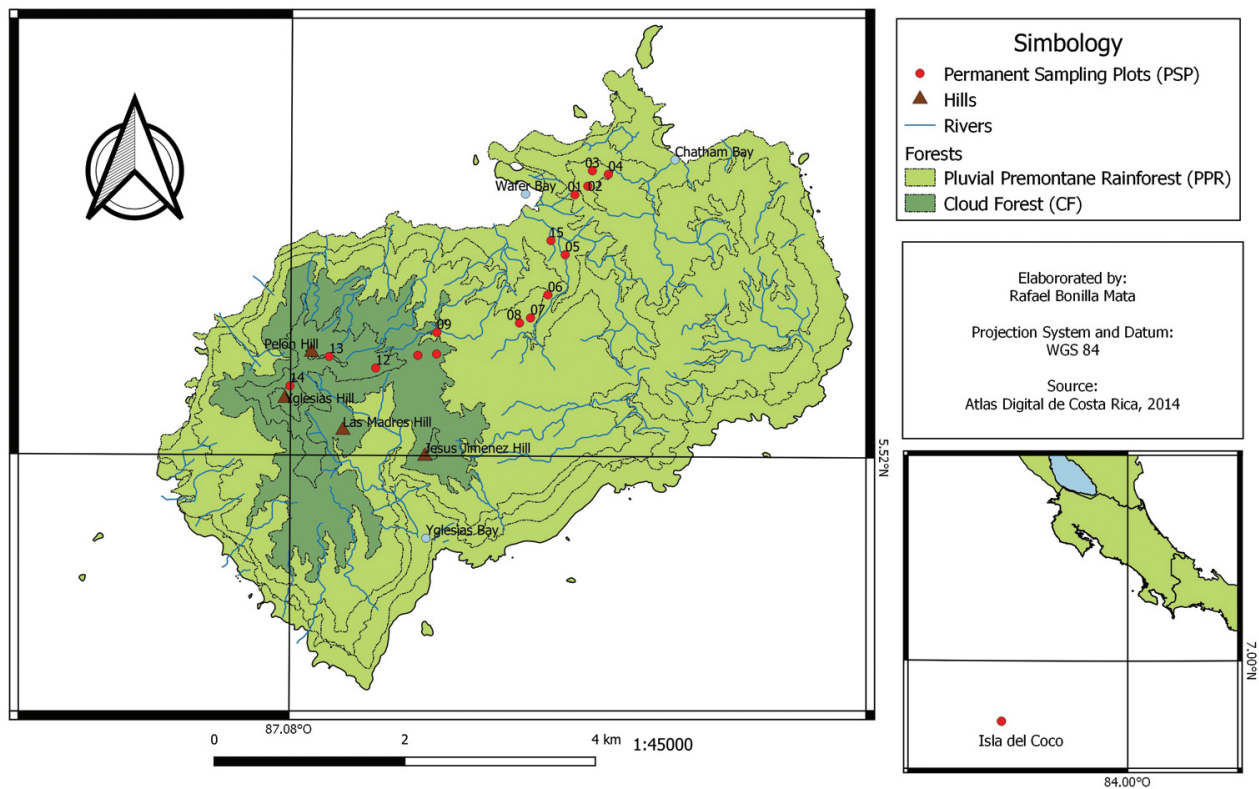

Fig. 1. Permanent sample plots established in the Premontane Pluvial Rainforest (PPR) and the Cloud Forest (CF). Isla del Coco National Park, Costa Rica, 2017. 
individuals in the last measurement, $\Delta \mathrm{T}$ : Time differential $(5,6,11$ years $)$.

Recruitment: The annual recruitment rate used the model of Phillips et al., (1994)

$$
\mathrm{Rr}=(\ln (\mathrm{No}-\mathrm{Nm}-\mathrm{Nr})-\ln (\mathrm{No}-\mathrm{Nm})) / \Delta \mathrm{t},
$$

Rr: Recruitment rate, No: Number of individuals in the first measurement; Nm: Number of dead individuals in the last measurement, $\mathrm{Nr}$ : Number of trees recruited in the last measurement, $\Delta \mathrm{T}$ : Time differential $(5,6,11$ years $)$.

Regeneration: In each PSP, two transects of 1 x $50 \mathrm{~m}$ were established for regeneration sampling, corresponding to an intensity of $4 \%$ of the PSP area. The regeneration of the same species surveyed in the PSP was identified at the species level, abundance recorded, and classified into seedlings of 0.3-1.5 m of height, and low saplings from 1.5 height to $4.9 \mathrm{~cm}$ of diameter (Louman et al., 2001).

Growth rate: We calculated the average growth rate (AGR) for both the diameter and the basal area by diametric category using the baseline data obtained by Rivera (2006) and Porras (2012). The growth analysis was conducted on forests and tree species. Two periods of growth were used for the Premontane Pluvial Rainforest: 2006-2017 (PPR 20062017) and 2012-2017 (PPR 2012-2017), for the Cloud Forest the period used was 2012-2017) (CF 2006-2017). The average growth rate was calculated as follows

$$
\operatorname{AGR}=\left(x_{1}-x_{2}\right) / t,
$$

$\mathrm{x}_{1}$ : diameter or final basal area, $\mathrm{x}_{2}$ : diameter or initial basal area and t: Time. (5, 6, 11 years).

Data analysis: Mortality, recruitment, regeneration, and growth analyses were carried out for forests and species, and the values obtained extrapolated to hectare (ha). We reported the results using the confidence intervals $(\alpha=0.05)$, the T-test was applied for independent samples to compare between forests and species. The results were compared with the studies conducted by Rivera (2006) and Porras-Jiménez (2012).

\section{RESULTS}

The statistical test showed differences between forests and species in growth patterns, mortality, recruitment, and regeneration.

Global patterns in forests population: In terms of mortality, the PPR reported mortality of 61 ind./ha. $( \pm 42 ; \mathrm{SD}=55 ; \mathrm{N}=9)$ and an annual mortality rate of $5.75 \%$. The $\mathrm{CF}$ mortality rate was 339 ind./ha. $( \pm 96 ; \mathrm{SD}=91$; $\mathrm{N}=6$ ), representing a yearly mortality rate of $6.31 \%$, in the period 2012-2017. Mortality between forests types is significant (Media test: $\mathrm{p}<0.0001 ; \mathrm{N}=15$ ), being higher in the Cloud Forest.

The recruitment for the period 2012-2017 in the PPR was 104 ind./ha. $( \pm 48$; $\mathrm{SD}=62$; $\mathrm{N}=$ 9), for an annual rate of $5.38 \%$, and in the $\mathrm{CF}$ was 205 ind./ha. $( \pm 84 ; \mathrm{SD}=76 ; \mathrm{N}=6)$ for an annual rate of $5.90 \%$. Recruitment is statically different $(\mathrm{p}<0.0001 ; \mathrm{N}=15)$.

The regeneration found in the PPR was 4867 seedlings/ha $( \pm 1772 ; \mathrm{N}=9)$ and 789 low saplings/ha $( \pm 325 ; \mathrm{N}=9)$. The $\mathrm{CF}$ reported 8217 seedlings/ha $( \pm 4936 ; \mathrm{N}=6)$, and 483 low saplings/ha $( \pm 437 ; \mathrm{N}=6)$. The global account of regeneration reported a significant difference between forests $(\mathrm{p}<0.05 ; \mathrm{n}=29)$.

Population structure in both forests showed a $J$ inverted pattern characteristic of an uneven-aged forest, and both forests reported individuals in all diametric classes (Fig. 2). An important characteristic of the $\mathrm{CF}$ population is the high number of individuals in the classes: seedlings 8217 ind./ha. ( \pm 4 936; $\mathrm{N}=6), 59$ $\%$ more than in the PPR, and 5-10 cm 1167 ind./ha. $( \pm 352 ; \mathrm{N}=6), 643.7 \%$ more than the PPR. This huge difference between forests was because of the high abundance of $C$. alfonsiana in the lower strata which represents $91.9 \%$, or 1072 ind./ha. $( \pm 417 ; \mathrm{N}=6)$ in the class $5-10$ $\mathrm{cm}$, given as result a dense understory. 

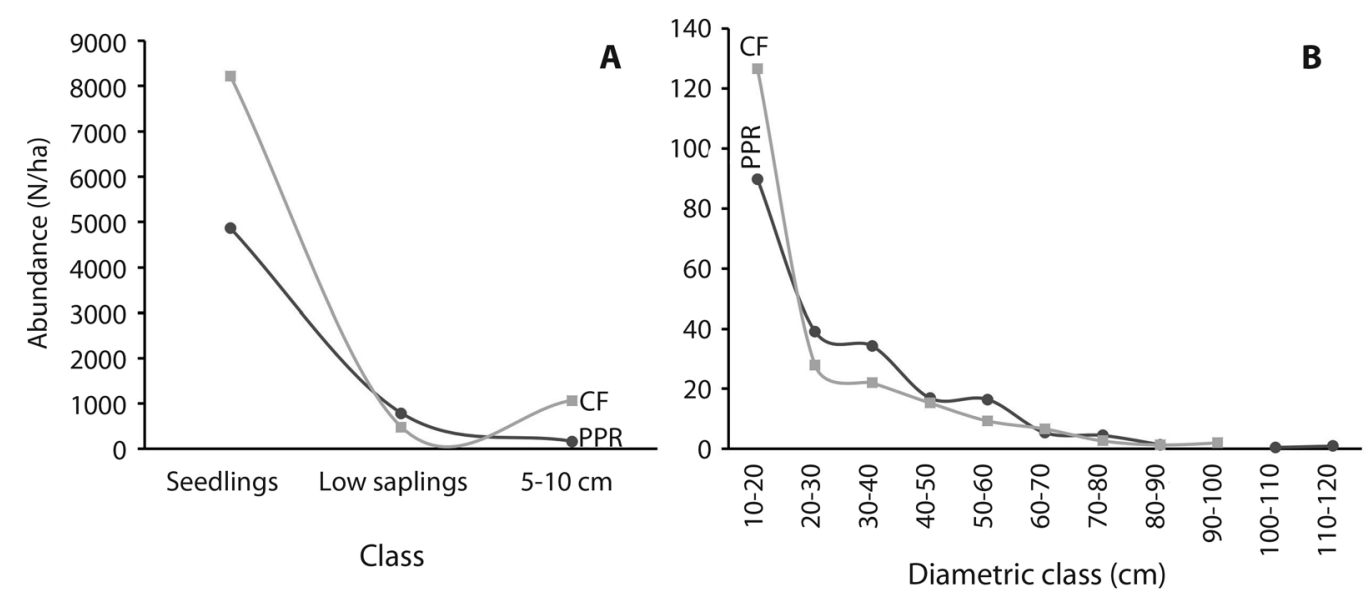

Fig. 2. Diametric distribution of the abundance (N/ha) for regeneration and individuals less than $10 \mathrm{~cm}(<10 \mathrm{~cm})(\mathrm{A})$ and for individuals $>10 \mathrm{~cm}$ (B), Premontane Pluvial Rainforest and the Cloud Forest, Isla de Coco National Park, Costa Rica, 2017.

Species analysis in the Premontane Pluvial Rainforest: A more significant variation was found between the results of previous years (Fig. 3). Sacoglottis holdridgei dominates the canopy, in 2012 it represented $45 \%$ of all species recruited, but in 2017 it represented $23 \%$, reflecting a reduction in recruitment of $15 \%$. Mortality reached 20 ind./ha. $( \pm 18$; SD $=23 ; \mathrm{N}=9$ ), representing $30 \%$ of the total mortality of the species found (Fig. 3E and Fig. 3F). The regeneration reported 56 ind./ha. $( \pm 41 ; \mathrm{SD}=53, \mathrm{~N}=9$, Fig. $3 \mathrm{G})$ in the seedlings class, low sapling was not reported. The diametric distribution by species showed that $S$. holdridgei supported the forest structure over $15 \mathrm{~cm}$ in diameter, confirming its dominance in this forest (Fig. 4).

Ocotea insularis trees produce many shoots under DBH. In the period 2012-2017 they only report recruitment and mortality on their shoots, but no new individuals. Additionally, $O$. insularis reported 122 seedlings/ha $( \pm 84 ; N=9)$, but low sapling was not reported.

Melastomataceae species increased their abundance in the last years, mainly H. succosa, which passed from $19 \%$ in 2006 to $31 \%$ in 2017. On the other hand, mortality was 23 ind./ ha. $( \pm 20 ; \mathrm{SD}=26, \mathrm{~N}=9)$. Furthermore, H. succosa had the highest regeneration, accumulating $28 \%$ of the individuals found. It is reported in greater quantities in clearings caused by the fall of death or large trees, where $H$. succosa was the most abundant with 1600 ind./ha. $( \pm 1$ 230; $\mathrm{SD}=886, \mathrm{~N}=9$; Fig. $3 \mathrm{G}$ ).

In terms of regeneration, $H$. succosa is the most abundant species. The species complex of the Melastomataceae family (include H. succosa, H. odorata, Miconia dodecandra) supports $J$-inverse forest structure in the low classes of seedlings and low-saplings.

Species analysis in the Cloud Forest: In this forest, the species dynamics were more stable in the years of study (Fig. 3D). The species with the highest mortality was the tree fern C. alfonsiana with 272 ind./ha. $( \pm 121$; SD $=$ $115, \mathrm{~N}=6$ ), representing $80 \%$ of the mortality for this forest, in turn, it had the highest recruitment with 155 ind./ha. $( \pm 89$; $\mathrm{SD}=84, \mathrm{~N}=6)$. Its regeneration reported 2667 seedlings/ha $( \pm 2$ 151; $\mathrm{SD}=2050, \mathrm{~N}=6$ ), and did not report low saplings. The upper canopy species did not present recruitment or mortality in the CF.

Forests growth in diameter: The forests reported different increases in diameter being those statistically different in the same period 2012- 2017 ( $\mathrm{p}=0.0414 ; \mathrm{n}=15$, Fig. 3A). In the Premontane Pluvial Rainforest, the increase in the period 2006-2017 was $0.29 \mathrm{~cm} /$ 

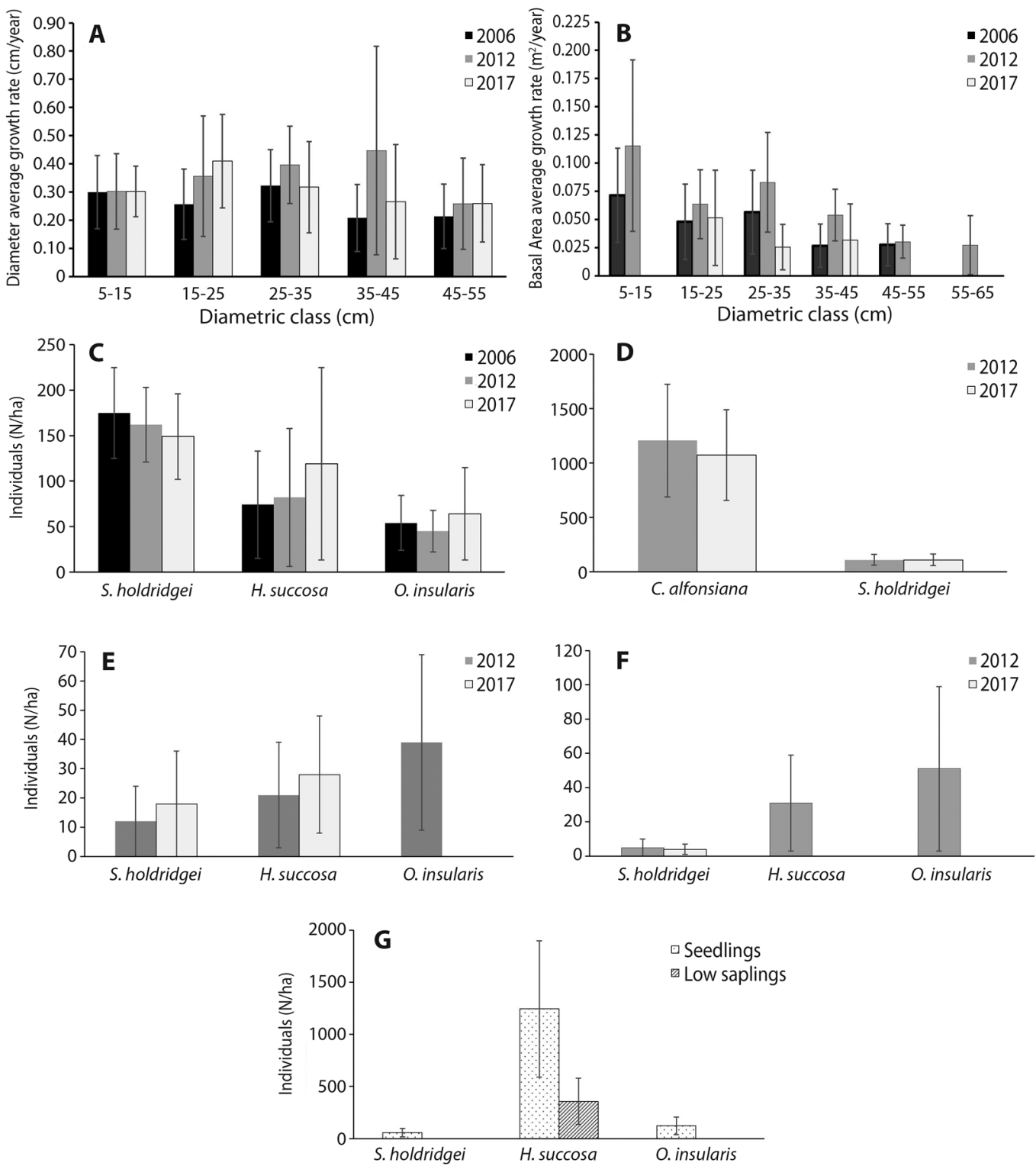

Fig. 3. Dynamics and growth of the forests: A) average growth rate in diameter ( $\mathrm{cm} /$ year) per year, B) average growth rate in basal area ( $\mathrm{m}^{2} /$ year), C) abundance of each species (N/ha) in the Premontane Pluvial Rainforest (PPR), D) abundance (N/ ha) in the Cloud Forest (CF), and E) mortality (N/ha), F) recruitment (N/ha), and $\mathbf{G})$ regeneration (N/ha) in the PPR, Isla del Coco National Park, Costa Rica, 2017.

year $( \pm 0.08 ; \mathrm{SD}=0.09 ; \mathrm{N}=523)$, and during period 2012- 2017 it was $0.34 \mathrm{~cm} /$ year $( \pm 0.09$, $\mathrm{SD}=0.07 ; \mathrm{N}=807)$; the growth rates reported were statistically different between periods ( $p$ $=0.0044 ; \mathrm{N}=5$ ).

On the other hand, the cloud forest showed annual diametric growth for the period
2012-2017 of $0.33 \mathrm{~cm} /$ year $( \pm 0.07$; $\mathrm{SD}=0.07$; $\mathrm{N}=366)$. The largest increases reported were in the categories $15-25 \mathrm{~cm}$ and $25-35 \mathrm{~cm}$ for both forests (Table 1).

Forests growth in basal area: The PPR reported in 2017 a basal area of $21.01 \mathrm{~m}^{2} / \mathrm{ha}$ 


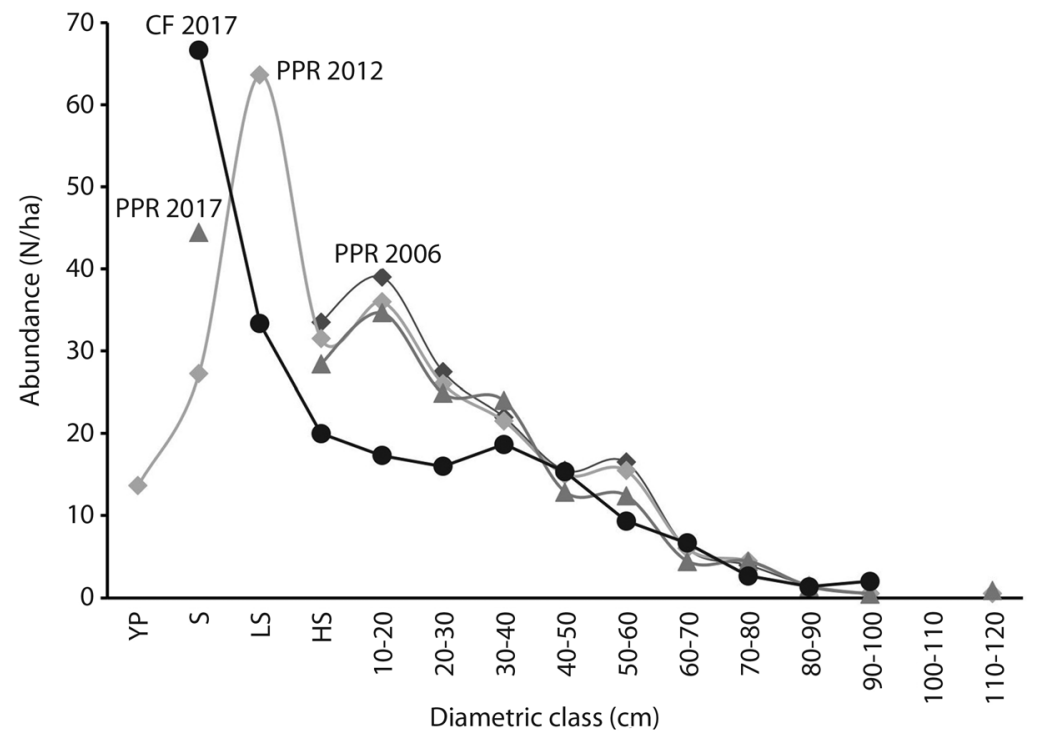

Fig. 4. Population structure of Sacoglottis holdridgei in three different times: 2006 (Rivera, 2006), 2012 (Acosta-Vargas, 2016), and 2017 (present study), for the Premontane Pluvial Rainforest (PPR) and the Cloud Forest (CF), Isla del Coco National Park, Costa Rica.

TABLE 1

Diametric and basimetric increment of the periods of study for the Premontane Pluvial Rainforest (PPR) and Cloud Forest (CF), Isla del Coco National Park, Costa Rica.

\begin{tabular}{|c|c|c|c|c|c|c|c|c|c|c|c|c|}
\hline & \multicolumn{12}{|c|}{ Diametric increase $\left(\mathrm{cm} \mathrm{year}^{-1}\right)$} \\
\hline & \multicolumn{4}{|c|}{ PPR 2006-2017 } & \multicolumn{4}{|c|}{ PPR 2012-2017 } & \multicolumn{4}{|c|}{ CF 2012-2017 } \\
\hline & $\mathrm{X}$ & $\mathrm{CL}$ & SD & $\mathrm{N}$ & $\mathrm{X}$ & $\mathrm{CL}$ & SD & $\mathrm{N}$ & $\mathrm{X}$ & $\mathrm{CL}$ & SD & $\mathrm{N}$ \\
\hline Forest & 0.29 & 0.08 & 0.09 & 523 & 0.34 & 0.09 & 0.07 & 807 & 0.33 & 0.07 & 0.07 & 366 \\
\hline Specie & - & - & - & - & - & - & - & - & - & - & - & - \\
\hline O. insularis & 0.50 & 0.30 & 0.36 & 159 & 0.57 & 0.30 & 0.39 & 74 & 0.27 & 0.23 & 0.22 & 87 \\
\hline H. succosa & 0.19 & 0.09 & 0.11 & 70 & 0.26 & 0.1 & 0.13 & 182 & - & - & - & - \\
\hline H. fascicularis & - & - & - & - & - & - & - & - & - & - & - & - \\
\hline \multirow[t]{4}{*}{ S. holdridgei } & 0.25 & 0.05 & 0.06 & 278 & 0.31 & 0.08 & 0.1 & 312 & 0.32 & 0.12 & 0.29 & 156 \\
\hline & \multicolumn{12}{|c|}{ Basimetric increase $\left(\mathrm{m}^{2} \mathrm{ha}^{-1}\right.$ year $\left.^{-1}\right)$} \\
\hline & \multicolumn{4}{|c|}{ PPR 2006-2017 } & \multicolumn{4}{|c|}{ PPR 2012-2017 } & \multicolumn{4}{|c|}{ CF 2012-2017 } \\
\hline & $\mathrm{X}$ & $\mathrm{CL}$ & SD & $\mathrm{N}$ & $\mathrm{X}$ & $\mathrm{CL}$ & SD & $\mathrm{N}$ & $\mathrm{X}$ & $\mathrm{CL}$ & SD & $\mathrm{N}$ \\
\hline Forest & 0.306 & 0.101 & 0.121 & 523 & 0.433 & 0.129 & 0.167 & 807 & 0.260 & 0.092 & 0.088 & 366 \\
\hline Specie & - & - & - & - & - & - & - & - & - & - & - & - \\
\hline O. insularis & 0.106 & 0.064 & 0.061 & 74 & 0.145 & 0.126 & 0.164 & 74 & - & - & - & - \\
\hline H. succosa & 0.015 & 0.013 & 0.016 & 70 & 0.040 & 0.038 & 0.050 & 182 & - & - & - & - \\
\hline H. fascicularis & - & - & - & - & - & - & - & - & - & - & - & - \\
\hline S. holdridgei & 0.187 & 0.053 & 0.063 & 278 & 0.232 & 0.05 & 0.07 & 312 & 0.171 & 0.060 & 0.057 & 156 \\
\hline
\end{tabular}

X: Average; CL: Confidence limits (95\%); SD: Standart Desviation; N: Sample. 
$( \pm 5.47 \mathrm{SD}=5.22 ; \mathrm{N}=9)$; compared with the previous surveys it represents an increase of $0.13 \mathrm{~m}^{2} / \mathrm{ha}$ in the period 2006-2017 and a decrease of $-0.20 \mathrm{~m}^{2} / \mathrm{ha}(0.92 \%)$ in the period 2012-2017. The Cloud Forest registered a basal area of $20.95 \mathrm{~m}^{2} / \mathrm{ha}( \pm 3.54 ; \mathrm{SD}=3.37$; $\mathrm{N}=6)$; this value decreased $-0.58 \mathrm{~m}^{2} / \mathrm{ha}(2.7$ $\%)$ compared to the 2012 baseline. Increases between forests are not statistically different for the period 2012-2017 ( $\mathrm{p}=0.2778 ; \mathrm{N}=15$; Fig. 3B; Table 1).

Growth of canopy species: Ocotea insularis presented the largest diametric increase in BPP in the period 2006-2017 with $0.50 \mathrm{~cm} /$ year $( \pm 0.30$; $\mathrm{SD}=0.36 ; \mathrm{N}=156)$, and in the period 2012- $20170.57 \mathrm{~cm} /$ year $( \pm 0.41 ; \mathrm{SD}=$ $0.39, \mathrm{~N}=144$ ); in the Cloud Forest the increase was $0.27 \mathrm{~cm} /$ year $( \pm 0.23 ; \mathrm{SD}=0.22 ; \mathrm{N}=56)$. For the 2012-2017 period for both forests, the reported growth is statistically different $(\mathrm{p}<$ $0.0001 ; \mathrm{N}=15$ ).

Sacoglottis holdridgei in PPR (2012-2017) reported an increase of $0.31 \mathrm{~cm} /$ year $( \pm 0.08$; $\mathrm{SD}=0.10 ; \mathrm{N}=312)$ and in the period 2006$20170.25 \mathrm{~cm} /$ year $( \pm 0.05 ; \mathrm{SD}=0.06 ; \mathrm{N}=$ 278). The Cloud Forest reported an increase of $0.32 \mathrm{~cm} /$ year $( \pm 0.12 ; \mathrm{SD}=0.10 ; \mathrm{N}=156)$. In the same period the diametric growth between the PPR and CF was not statistically different $(\mathrm{p}=0.8772 ; \mathrm{N}=15)$. Sacoglottis holdridgei is the only species that presents individuals in all diametric categories.

Henriettea succosa: presented an increase of $0.19 \mathrm{~cm} /$ year $( \pm 0.11 ; \mathrm{SD}=0.13 ; \mathrm{N}=70)$ for BPP 2006-2017 and 0.26 cm/year $( \pm 0.10$; $\mathrm{SD}=0.13 ; \mathrm{N}=182$ ) for BPP 2012-2017. This species is absent in Cloud Forest.

Basal area growth by species: In the Premontane Pluvial Rainforest S. holdridgei reported in $201714.84 \mathrm{~m}^{2} / \mathrm{ha}( \pm 5.78 ; \mathrm{SD}=5.5$, $\mathrm{N}=9$ ) a lower value than in 2012, corresponding to a reduction in basal area of $0.58 \mathrm{~m}^{2} /$ ha $(3.8 \%)$; Similarly, $O$. insularis reported a loss of $0.11 \%$. All Melastomataceae species surveyed reported an increase of $0.27 \mathrm{~m}^{2} / \mathrm{ha}$ (1.3\% of total basal area 2017); especially,
H. succosa which represented $68.8 \%$ of the increased basal area, and $32.1 \%$ of the basal area loss by $S$. holdridgei (Fig. 5).

For the Cloud Forest in 2017, S. holdridgei registered $13.25 \mathrm{~m}^{2} / \mathrm{ha}( \pm 4.32 ; \mathrm{SD}=4.12, \mathrm{n}$ $=6$ ), and only $0.9 \%$ of basal area loss. The species with the biggest impact was $C$. alfonsiana with a loss of $3.75 \%$, which in 2017 accumulated $4.20 \mathrm{~m}^{2} / \mathrm{ha}( \pm 2.69 ; \mathrm{SD}=2.56$, $\mathrm{N}=6$ ). Ocotea insularis was the species that reported the greatest increase with $0.32 \mathrm{~m}^{2} /$ ha corresponding to a $1.5 \%$ recovery of the basal area and followed by Melastomataceae with an increase of $0.34 \%$ (Fig. 5).

\section{DISCUSSION}

Due to the increasing anthropogenic degradation of forests, investigations in forest dynamics and growth for conservation and restoration are necessary. For Isla del Coco National Park forests, these investigations are unknown, but are highly required, from degradation caused by because of introduced herbivores and climate change.

Added to the isolation, the small size of Isla del Coco combined with a little altitudinal gradient (0-620 m.a.s.1), we found significant statistical differences in recruitment, mortality, regeneration and growth rates between both forests. Even though, the PPR and CF share the same canopy species, dynamic and ecological process, along with abiotic factors and geological origin (Castillo et al., 1988; Bergoeing, 2012) made them different as a response for adaptation. That condition only reaffirmed that this is an ecosystem of great diversity (Trusty et al., 2006) and complexity.

Patterns in species and their influence in forests: Here, we presented the results for the periods 2006-2017 and 2012-2017 which showed different patterns. The mortality in the ICNP's forests reached higher values than in continental mature tropical forests that range from 0.9 to $2.91 \%$ (Marín, Nygard, Rivas, \& Oden, 2005). Also, it was even higher than the 

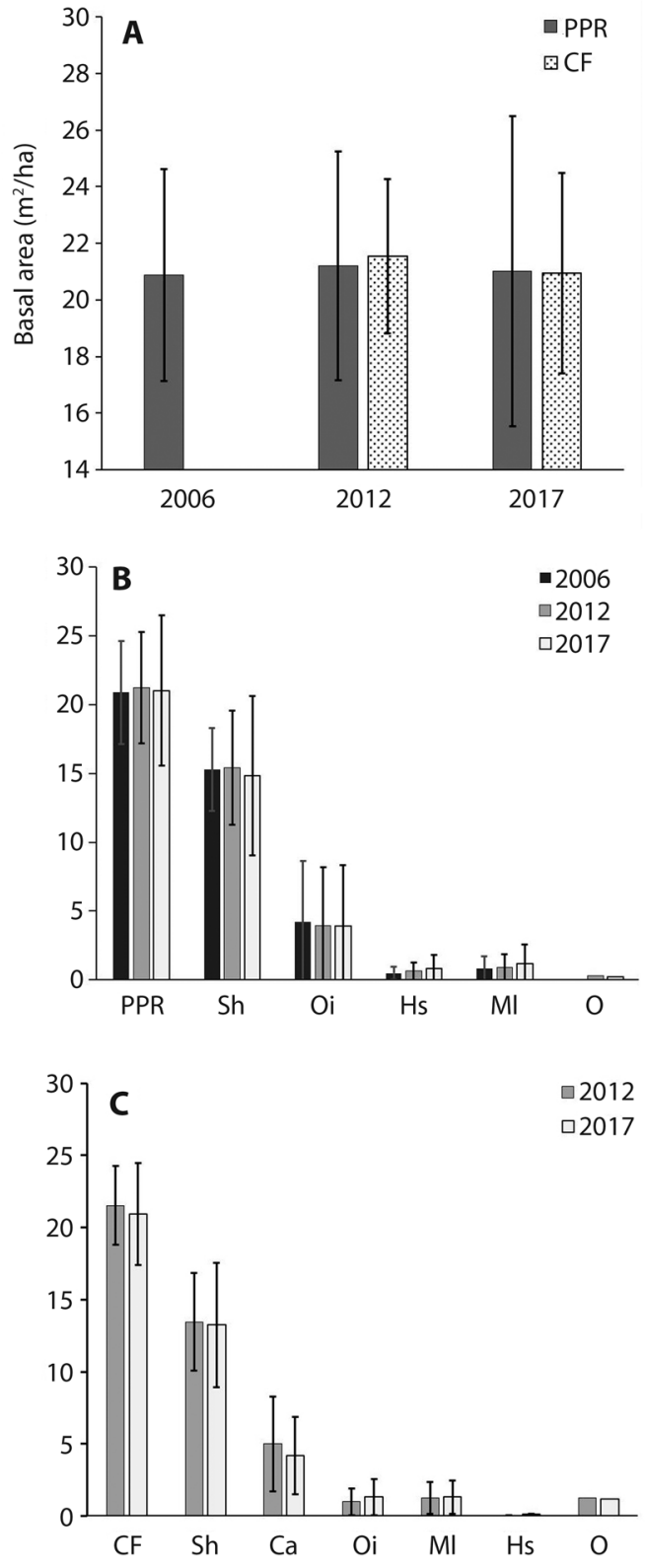

Fig. 5. A) Basal area comparison per type of forest (PPR: Premontane Pluvial Rainforest and CF: Cloud Forest) in three different times of measurement: Rivera (2006), Porras-Jiménez (2012) and present study (2017). B) Basal area comparison between species in the PPR and $\mathbf{C}$ ) in the CF (Sh: Sacoglottis holdridgei, Ca: Cyathea alfonsiana, Oi: Ocotea insularis, Hs: Henriettea succosa, Ml: other Melastomataceae species, and $\mathrm{O}$ : other species) in three different times of measurement (2006, 2012, 2017). Isla del Coco National Park, Costa Rica.
2.99 \% reports by Porras-Jiménez (2012) during the period 2006-2012.

This condition of mortality for this window of 12 years of observation in the PPR showed that values around $3 \%$ are characteristic of Isla del Coco. Moreover, we can associate this with a new period of forest dynamics, reflected in the high mortality of $65 \%$ at a canopy level by individual replacement, and a resources liberation. Sacoglottis holdridgei accumulated all the mortality, and in contrast, H. succosa took advantage and recruiting $38 \%$ of individuals, and $71 \%$ of the total regeneration.

This pattern was observed in 2013 (Acosta-Vargas, 2016), where species of Melastomataceae family represented $45 \%$ of the regeneration. Here, we see a sustained increase in Melastomataceae dominance.

In the period 2006-2017 the PPR grew in diameter at a rate of $0.29 \mathrm{~cm} /$ year, a higher rate than the one reported by Porras-Jiménez (2012) of $0.20 \mathrm{~cm} /$ year in the period 2006-2012. In the time frame 2012-2017, the rate increased to $0.34 \mathrm{~cm} /$ year, as a result of higher growth rates in the species $S$. holdridgei, $O$. insularis, and $H$. succosa. As a direct result, the growth in the basal area increased for the same period reaching $0.433 \mathrm{~m}^{2} / \mathrm{ha} /$ year. This acceleration in growth is the result of the release of resources by mortality, mainly large trees of $S$. holdridgei. The remaining stand grows and recovers the basal area within the values that the site can support. This type of condition has been reported in forests of La Cangreja National Park (Acosta-Vargas, 2012) and the Osa Peninsula, Costa Rica, (Quesada-Monge, Acosta-Vargas, Garro-Chavarría, \& Castillo-Ugalde, 2012).

The species presented a diametric and basal area increase according to their ecological guild. The Melastomataceae species recorded are durable heliophytes; all are fast-growing, relatively long-lived and need light for their establishment; meanwhile, $O$. insularis and S. holdridgei are shade tolerant. Sciophytes have less growth than heliophytes, but their growth increases if a canopy opening happens because those species require a percentage of 
light to move from intermediate diametric categories to maturity, (Porras-Jiménez, AcostaVargas, Quesada-Monge, \& Castillo-Ugalde, 2014; Finegan, 1993; Lamprecht, 1990). It was seen that durable heliophyte species showed the highest increase in both forests, similar to performance was reported in a natural forest in Venezuela (Ramírez, Acevedo, Ataroff \& Torres 2009).

The Cloud Forest showed a more stable dynamic at canopy level in contrast with PPR, whose the recruitment rate is under the mortality rate. In terms of individuals, they are nearly balanced with a net loss of $0.37 \%$ in the PPR, and $0.41 \%$ in the CF, a pattern reported in continental forests (Lieberman, Lieberman, Peralta, \& Hartshorn, 1985).

Furthermore, this stability is usual for a forest in the homeostatic stage. The most critical changes in the CF were at the low canopy with a high rate of mortality of $C$. alfonsiana, which reached $80 \%$ but also reported high recruitment and regeneration. In particular, C. alfonsiana is a key species defining the CF structure.

These patterns of mortality, recruitment, and regeneration presented two conditions. First, the forest structure fits the $J$-inverted model, typical of uneven-age forest (Lamprecht, 1990). This population structure supposes a guarantee of permanence in the time because of the stock of young trees that will reach the canopy.

The second is the abundance of canopy species, from which $S$. holdridgei is the species close to fit the $J$-inverted model above a $\mathrm{DBH}>5 \mathrm{~cm}$. Although, its regeneration is low, and by 2017 it replicates the trend reported in 2013 (Acosta-Vargas, 2016). Above DBH > 20 $\mathrm{cm} S$. holdridgei define the forest population structure; in this sense, it is a mono-specific forest, and $S$. holdridgei shapes the heights and the structure of the canopy. Ocotea insular is a companion species, and its population structure is incomplete in both forests.

Overall, Sacoglottis holdridgei is the most important species in the forest dynamics of the ICNP because it is an endemic species and presents a continuous horizontal distribution (Porras-Jiménez et al., 2014). Comparing the current state of the population of $S$. holdridge with the reported by Acosta-Vargas (2016), some changes happened in four years, when the population structure looked improving the regeneration for 2017, at least for seedlings (0.3-1.5m), but young plants $(0-0.3 \mathrm{~m})$ and low saplings did not report individuals (Fig. 4). Dissimilarities found are related to factors such as spatial distribution, because the regeneration counted was in $50 \%$ of the same sites surveyed in $2013,33 \%$ did not register regeneration both in 2013 and 2017; this means that regeneration has not taken place in some areas of Isla del Coco because of filters that avoid its establishment such as: seed predation by micromoth larvae (Blastobasidae) that affects $70 \%$ of the fruits (Retana-Corrales, 2018), pigs' effects by soil removal (Sierra, 2001), and rats that gnawed $68 \%$ of the fruits (Gómez, 2004); also a depleted seed bank, herbivory and absence of disperser (Acosta-Vargas, Rovere, CamachoSandoval 2020).

Another important aspect is that since 2006, the population of $S$. holdridgei has been decreasing (Rivera, 2006, Fig. 4), evidencing the high mortality rate and limited recruitment in the PPR that starts from the lowest diametric class. In the case of the $\mathrm{CF}$, population was stable. Comparing the CF with the PPR, the Cloud Forest presents an older population because the abundance in the diametric classes between $10-40 \mathrm{~cm}$ is an average $35 \%$ lower than in the PPR. It talks to the topic of forest limitations and a global problem of tree replacement in the medium and long term (Fig. 4).

This species ( $S$. holdridgei) also had the highest mortality in all the diametric categories and reported low values of recruitment and regeneration, unlike other species. In comparison with the data obtained by Acosta-Vargas (2016) of $27 \pm 20$ seedlings/ha, S. holdridgei reported an increase in the number of low saplings/ha with $56( \pm 41 ; \mathrm{SD}=53, \mathrm{~N}=9$; Fig. 1d), but there are no significant differences (CL $\alpha=$ 
0.05); however, it did not report any individuals in the low sapling category.

Forecasting forest changes and their impacts on diversity: What is happening nowadays in the Isla del Coco's forests is a transformation of its structure and composition. A process that took place decades ago with the introduction of herbivores and potentially increased affect with climate change. Changes are stronger in the Premontane Pluvial Rainforest (PPR), where the continuous stress caused by white-tailed deer and pigs is still going on. This change brings with it the loss of dominance of $S$. holdridgei, and this induces a shift in forest vertical and horizontal structure.

The change that the forest faces leads to the substitution of $S$. holdridgei with Melastomataceae species, and especially $H$. succosa, all them middle canopy species. This species replacement will create a dramatic shift in the future forest with a tremendous impact in microclimate conditions, and ecological processes such as birds nesting, epiphytic support, and seed banks. The forest structure is modified, losing canopy height and even a less long-lived forest species. Finally, the epiphyte biodiversity of bromeliads, orchids, and ferns will be affected by the loss of the substratum provided by the old Sacoglottis trees.

Everything described above was recorded in PSP 5 in the period 2012-2017. This PSP had the highest mortality of trees at the canopy, 58 $\%$ corresponding to Sacoglottis, and the highest recruitment and regeneration of individuals of Melastomataceae family, mainly $H$. succosa represented $70 \%$ of individuals' recruitment and regeneration.

Henriettea succosa is a durable heliophyte species. As a pioneer species it occupies clearings for its establishment and needs light for its development (Lamprecht, 1990). So, the space realized by the death of trees in the canopy is occupied by H. succosa in the absence of fastgrowing species belonging to the upper strata, and regeneration of the dominant species $S$. holdridgei and $O$. insularis.

In the long term, the greenery of Isla del Coco will be keep, but it will be supported by another kind of forest in structure and species composition. Here, we emphasize the herbivores caused damage, as ecosystem engineers who are altering the native forest and species population. White-tailed deer and pigs' impact on the island is enormous; their introduction created an incomplete trophic chain, characterized by the absence of predators that can control their population. Around 300 years of pigs' presence and 80 years of white-tailed deer presence is not enough time for ecosystem and species to adapt, to evolve and to deal with the new members.

But not everything is wrong, PSP 5 presented the largest diametric increase with $0.60 \mathrm{~cm} /$ year $( \pm 0.09 ; \mathrm{SD}=0.39 ; \mathrm{N}=78)$ in the period 2012-2017. Consequently, all the species surveyed in this plot speeded their growth. Henriettea succosa showed a diametric increase of $0.45 \mathrm{~cm} /$ year $( \pm 0.08$; $\mathrm{SD}=0.26$; $\mathrm{N}=38$ ); while $O$. insularis and $S$. holdridgei, both shade tolerant, reported $0.94 \mathrm{~cm} /$ year $( \pm 0.27 ; \mathrm{SD}=0.53 ; \mathrm{N}=17)$ and $0.54 \mathrm{~cm} /$ year $( \pm 0.14 ; \mathrm{SD}=0.29 ; \mathrm{N}=20)$ respectively.

This increase is even higher than the previous period from 2006 to 2012. This dynamic pattern was explained by Finegan (1993): shade-tolerant species trend to increase their diameter if openings in the canopy take place, which is the pattern reported for forests in the Central Pacific of Costa Rica (Acosta-Vargas 2012), and the Osa Peninsula (Quesada et al., 2012). This condition will result in trees with larger diameters, which balance the basal area supported by the site.

The need to act: Isla del Coco National Park is a unique site, due to its endemism, climate, and native fauna and flora. Joined with its history, beauty, and breathtaking landscapes helped it to be become declared a World Heritage and Humanity and Wetland RAMSAR site. No matter those prestigious designations for preservation, threats still affect the forest future.

The tree canopy species have not been regenerated and recruited at the same rate that equates with their mortality. In the future, the 
forest will present a change in the current structure and composition, mainly in the PPR rather than in the CF.

The CF may be more sensitive to the El Niño phenomena, due to changes in the cloudiness pattern and horizontal rain. Furthermore, tree canopy death will bring drier conditions affecting the rich fern community at the understory level.

As a way of stopping degradation for restoring the forest, control of herbivores is mandatory and urgent, just if the idea is to preserve the native flora and fauna of Isla del Coco.

We recommend active forest restoration, increase PSP net, climate monitoring, and more investigation in ecology to fill up information gaps. In this way, we can better understand and help the ecosystem, especially the Cloud Forest.

Ethical statement: authors declare that they all agree with this publication and made significant contributions; that there is no conflict of interest of any kind; and that we followed all pertinent ethical and legal procedures and requirements. All financial sources are fully and clearly stated in the acknowledgements section. A signed document has been filed in the journal archives.

\section{ACKNOWLEDGMENTS}

We acknowledge Cocos Marine Conservation Area and the Isla del Coco National Park, the Costa Rica Institute of Technology and the "Project Influence of the micro-organism plant interaction in the restoration of the forest landscape of the Isla del Coco National Park", and Jacklyn Rivera and Michael Porras for their previous research in the Isla del Coco National Park. Also, many thanks to the anonymous reviewers who contributed to this article.

\section{RESUMEN}

Dinámica y crecimiento de los bosques del Parque Nacional Isla del Coco, Costa Rica Introducción: Las islas son esenciales para la biodiversidad mundial. El Parque Nacional Isla del Coco es una isla oceánica cubierta de bosques lluviosos tropicales; sin embargo, su ecología y el efecto de las especies introducidas son poco conocidos. Objetivo: Evaluar la mortalidad, el reclutamiento, la regeneración y el crecimiento de las especies arbóreas. Métodos: Se midieron 15 parcelas permanentes de muestreo (PPM), nueve en el bosque pluvial premontano (BPP) y seis en el bosque nuboso $(\mathrm{BN})$; Se midieron árboles con DAP $>5 \mathrm{~cm}$. El muestreo regeneración se realizó dentro de cada PPM, mediante dos transectos de 1 x $50 \mathrm{~m}$. Los datos se analizaron tomando como línea base las mediciones del 2006, 2012 y 2017. Resultados: En el período 2012-2017, la tasa de mortalidad anual en el BPP fue de 5,75\% y para el BN de $6,31 \%$. La tasa de reclutamiento anual en el BPP fue de $5.38 \%$ y $5.90 \%$ para BN. Para el BPP, la regeneración total registrada fue de 5656 individuos y 8700 para el BN. Sacoglottis holdridgei tuvo la mortalidad más alta y los valores más bajos de reclutamiento y regeneración. La estructura del bosque se ajusta al modelo J invertido para la mayoría de los bosques tropicales. Sacoglottis holdridgei define la estructura del bosque sobre diámetros $>20 \mathrm{~cm}$. Pero, en diámetros $<20 \mathrm{~cm}$ está fuertemente influenciado por $H$. succosa, especie que reportó la mayor abundancia de regeneración y reclutamiento. El aumento promedio anual del diámetro entre bosques fue estadísticamente diferente $(\mathrm{p}=0.0414 ; \mathrm{N}=15), 0.36 \mathrm{~cm} /$ año en el PPR y 0.33 $\mathrm{cm} /$ año en el CF. Conclusiones: El BPP y el BN difieren en los patrones de mortalidad, reclutamiento y regeneración, lo que confirma la singularidad de estos ecosistemas. Una regeneración más exitosa de $H$. succosa provocará cambios en la estructura y composición de los bosques, principalmente BPP. Los cambios en la estructura del bosque tendrán un fuerte impacto en la flora epífita, las condiciones de microclima y la anidación de aves como Gygis alba (Palomita del Espíritu Santo) debido a la pérdida de árboles maduros de Sacoglottis. La baja regeneración de S. holdridgei está asociada con la presencia de herbívoros introducidos, para restaurar el bosque es necesario su manejo.

Palabras clave: Estructura de bosque; mortalidad; reclutamiento; regeneración; crecimiento; área basal.

\section{REFERENCES}

Acosta-Vargas, L. G., Rovere, A. G., \& CamachoSandoval, J. (2020). Effectiveness of two treatments to promote tree regeneration: implications for forest restoration in the Isla del Coco National Park, Costa Rica. Revista de Biología Tropical, 68(Suppl. 1), S103-S114.

Acosta-Vargas, L. G. (2012). Análisis silvigénico de los bosques húmedos tropicales del Parque Nacional La Cangreja. (Thesis Licenciatura). Instituto Tecnológico de Costa Rica, Cartago, Costa Rica. 
Acosta-Vargas, L. G. (2016). Population status of tree Sacoglottis holdridgei (Humiricaceae). At Isla del Coco National Park, Costa Rica. Revista de Biología Tropical, 64(Suppl. 1), S263-S275.

Bergoeing, J. P. (2012). Geomorfología de la Isla del Coco, Costa Rica. Revista Geográfica, 151, 129-138

Bolívar, A., Rovinsky, Y., \& Ching, E. W. (2000). La pesca en la Isla del Coco. Estudio integral para el mejoramiento del control pesquero en la zona de influencia del Área de Conservación Marina y Terrestre Isla del Coco (Informe técnico) San José, Costa Rica. Fundación Amigos de La Isla del Coco y Área de Conservación Marina y Terrestre Isla del Coco.

Bowman, D. M., Brienen, R. J., Gloor, E., Phillips, O. L., $\&$ Prior, L. D. (2013). Detecting trends in tree growth: not so simple. Trends in Plant Science, 18(1), 11-17.

Castillo, P., Batiza, R., Vanko, D., Malavassi, E., Barquero, J., \& Fernández, E. (1988). Anomalously Young volcanoes on old hot spot traces: I. Geology and petrology of Cocos Island. Geological Society of Bulletin, 100(9), 1400-1414.

Castillo-Ugalde, M. (1991). Establecimiento de parcelas permanentes de muestreo en bosque natural para evaluar el aprovechamiento forestal, Península de Osa, Costa Rica. (Proyecto de investigación). Instituto Tecnológico de Costa Rica, Cartago, Costa Rica.

Dirzo R. (2001). Plant-mammal interactions: Lessons for our understanding of nature, and implications for biodiversity conservation. In MC Press, NJ Huntly, S Levin (eds), Ecology: Achievement and challenge, (pp. 319-335). Blackwell Science, Oxford, UK.

Estrada-Chavaría, A., Sánchez-González, J., \& RodríguezGonzález, A. (2020). Catálogo actualizado de las plantas vasculares del Parque Nacional Isla del Coco, Costa Rica. Revista de Biología Tropical, 68(Suppl. 1), S73-S88.

Finegan, B. (1992). Bases ecológicas para la silvicultura. Tropical Centro Agronómico Tropical de Investigación y Enseñanza (CATIE). Turrialba, Costa Rica.

Finegan, B. (1993). Bases ecológicas de la silvicultura. I. Curso Intensivo Internacional de Silvicultura y Manejo de Bosques Naturales Tropicales. Centro Agronómico Tropical de Investigación y Ensenanza (CATIE), Turrialba, Costa Rica.

Gadow, K., Sánchez, S., \& Álvarez, J. (2007). Estructura y Crecimiento del Bosque. Santiago de Compostela, España: Universidad de Santiago de Compostela. .

Gómez, J. R. (2004). Estudio poblacional de los roedores introducidos y su impacto sobre la fauna nativa en la Isla del Coco. (Tesis de maestría). Universidad Nacional de Costa Rica, Heredia, Costa Rica.
Gutiérrez-Fonseca, P. E., Ramírez, A., Umaña, G., \& Springer, M. (2013). Macroinvertebrados dulceacuícolas de la Isla del Coco, Costa Rica: especies y comparación con otras islas del Pacífico Tropical Oriental. Revista de Biología Tropical, 61(2), 657-668.

Herrera, W. (1986). Clima de Costa Rica, Vol 2. L. D. Gómez (Ed.). Vegetación y Clima de Costa Rica. San José, Costa Rica: Editorial Universidad Estatal a Distancia (EUNED).

Janzen, D. H. (1970). Herbivores and the number of tree species in tropical forests. The American Naturalist, 104(940), 501-528.

Lamprecht, H. (1990). Silvicultura en los trópicos. Los ecosistemas forestales en los bosques tropicales y sus especies arbóreas, posibilidades y métodos para un aprovechamiento sostenido. Bonn, Germany: Deutsche Gesellschaft fur Technische Zusammenarbeit (GTZ) GmbH.

Lewis, S. L., Phillips, O. L., Sheil, D., Vinceti, B., Baker, T. R., Brown, S., ... \& Lejoly, J. (2004). Tropical forest tree mortality, recruitment and turnover rates: calculation, interpretation and comparison when census intervals vary. Journal of Ecology, 92(6), 929-944.

Lieberman, D., Lieberman, M., Peralta, R., \& Hartshorn, G. S. (1985). Mortality patterns and stand turnover rates in a wet tropical forest in Costa Rica. The Journal of Ecology, 915-924.

Louman, B., Quirós, D., \& Nilsson, M. (2001). Silvicultura de Bosques Latifoliados Húmedos con Énfasis en América Central. Serie técnica. Manual Técnico $N^{o}$ 46. Turrialba, Costa Rica: Centro Agronómico Tropical de Investigación y Enseñanza (CATIE), Turrialba, Costa Rica.

Madriz, P. (2009). El Parque Nacional Isla del Coco (PNIC): Una isla oceánica invadida. Revista Biocenosis. 22(1-2), 61-72.

Marín, G.S., Nygard, R, Rivas, B.G., \& Oden, P.C. (2005). Stand dynamics and basal area change in a tropical dry forest reserve in Nicaragua. Forest Ecology \& Management 208, 63-75

Monge, A. (1999). Estudio de la dinámica del bosque seco tropical a través de parcelas permanentes de muestreo en el Parque Nacional Palo Verde, Bagaces, Guanacaste, Costa Rica. (Thesis Bachillerato). Instituto Tecnológico de Costa Rica. Cartago, Costa Rica.

Montoya, M. (2016). Isla del Coco: Marine Ecosystem. En M. Kappelle (Ed.), Costa Rican Ecosystems. University of Chicago Press.

Nebel, G., Kvist, L. P., Vanclay, J. K., \& Vidaurre, H. (2001). Forest dynamics in flood plain forests in the Peruvian Amazon: effects of disturbance and implications for management. Forest Ecology and Management, 150(1), 79-92. 
Phillips, O.L., Hall, P., Gentry, A.H., Sawyer, S.A. \& Vásquez, R. (1994). Dynamics and species richness of tropical rain forest. Proceedings of the National Academy of Sciences of United States of America (USA). 91(7), 2805-2809

Porras-Jiménez, M. A. (2012). Dinámica de los bosques del Parque Nacional Isla del Coco, Área de Conservación Marina isla del Coco. (Thesis Licenciatura). Instituto Tecnológico de Costa Rica, Cartago, Costa Rica.

Porras-Jiménez, M.A., Acosta-Vargas, L., Castillo-Ugalde, M., \& Quesada-Monge, R. (2014). Estructura y composición florística del bosque nuboso de la Isla del Coco. Revista Tecnología en Marcha, 27, 22-36.

Quesada-Monge, R., Castillo-Ugalde, M., Lobo-Segura, J., \& Barrantes, G. (2010). Demografia de Especies Maderables de la Península de Osa. (Proyecto de investigación). Instituto Tecnológico de Costa Rica, Cartago, Costa Rica.

Quesada-Monge, R., Acosta-Vargas, L. G., Garro-Chavarría, M., \& Castillo-Ugalde, M. (2012). Dinámica del crecimiento del bosque húmedo tropical, 19 años después de la cosecha bajo cuatro sistemas de aprovechamiento forestal en la Península de Osa, Costa Rica. Tecnología en Marcha, 25(5), 55-66.

Retana-Corrales, I. (2018). Estado fitosanitario de la población de Sacoglottis holdridgei (Cuatrec.) y caracterización del lepidóptero frugivoro en el Parque Nacional Isla del Coco, Costa Rica. (Thesis Licenciatura sin publicar). Instituto Tecnológico de Costa Rica, Cartago, Costa Rica.
Ramírez, H., Acevedo, M., Ataroff, M. \& Torres, A. (2009). Crecimiento diamétrico de especies arbóreas en un bosque estacional de los llanos occidentales de Venezuela. Ecotrópicos 22(2): 46-63.

Rivera, W. J. (2006). Estructura y composición florística del bosque pluvial premontano en el Parque Nacional Isla del Coco, Área de Conservación Marina Isla del Coco. (Thesis Licenciatura). Instituto Tecnológico de Costa Rica, Cartago Costa Rica.

Sierra, C. (2001). El cerdo cimarrón (Sus scrofa, Suidae) en la Isla del Coco, Costa Rica: escarbaduras, alteraciones al suelo y erosión. Revista de Biología Tropical, 49(3-4), 1159-1170.

Sistema Nacional de Áreas de Conservación, Costa Rica (SINAC). (2016). Propuesta de actualización del Plan General de Manejo del Parque Nacional Isla del Coco 2017-2026. Eds. H. Acevedo V. Obando y \&. Villalobos. San José, Costa Rica. 143 p.

Trusty, J. L., Kesler, H. C., \& Delgado, G. H. (2006). Vascular flora of Isla del Coco, Costa Rica. Proceedings of the California Academy of Sciences, 57(7) 247-355

Valerio, J., Esquivel, E. \& Salas, C. (1998). Sistema de Parcelas Permanentes y Análisis de la dinámica del Bosque Natural. (Informe Final de Proyecto), Instituto Tecnológico de Costa Rica, Cartago, Costa Rica

Zamora, A. (2008). Estructura y composición florística de los bosques de bahía en el Parque Nacional Isla del Coco, Área de Conservación Marina Isla del Coco. (Thesis Licenciatura). Instituto Tecnológico de Costa Rica, Cartago, Costa Rica. 